\title{
EXPANDING PRIVATE RETIREMENT PLAN COVERAGE AND BENEFITS: \\ Proposals Before the Ninety- FIFTH AND NINETY-SIXTH CONGRESSES
}

\author{
Peter H. Turza*
}

In the United States the percentage of individuals sixty-five years of age or older is growing at a reinarkably rapid rate. In 1970, about ten percent of the population occupied this age bracket. By the year 2000 , this figure is projected to rise to twelve percent. ${ }^{1}$ If present demographic trends continue, by the year 2030 the sixty-five and over age group will number inore than fifty-one million people-roughly seventeen percent of the population. ${ }^{2}$ This apparently unavoidable aging of

* B.A. 1971, Yale University; J.D. 1974, Georgetown University Law Center. Mr. Turza is currently serving as Special Counsel to Senator Jacob K. Javits (R-N.Y.) for Employee Benefits.

THE FOLLOWING CITATIONS WILL BE USED IN THIS ARTICLE:

S. 209 (The ERISA Improvements Act of 1979), 96th Cong., 1st Sess., 125 CoNG. REc. S560 (daily ed. Jan. 24, 1979) [heremafter cited as S. 209];

S. 3140 (The Simplified Pension Plan Act), reprinted in Hearings on S. 3140 Before the Subcomm. on Private Pension Plans and Employee Benefits of the Senate Finance Comm., 95th Cong., 2d Sess. 3 (1978) [hereinafter cited as S. 3140];

S. 3017 (The ERISA Improvements Act of 1978), reprinted in Hearings on $S$. 3017, at 3 [heremafter cited as S. 3017];

H.R. 13576, 95th Cong., 2d Sess., 124 CoNG. REc. H7237 (daily ed. July 24, 1978) [heremafter cited as H.R. 13576];

Joint Hearings on S. 3017 Before the Subcomm. on Labor of the Senate Comm. on Human Resources and the Subcomm. on Private Pension Plans and Employee Fringe Benefits of the Senate Comm. on Finance, 95th Cong., 2d Sess. (1978) [heremafter cited as Hearings on S. 3017];

Report of the Comm on Finance of the Senate on H.R. 13511, S. REP. No. 1263, 95th Cong., 2d Sess. (1978), reprinted in [1978] U.S. CODE CONG. \& AD. News 6761 [heremafter cited as 1978 SENATE REPORT];

H. ShePpard \& S. Rix, The GraytNg OF WorkING AMERICA (1977) [heremafter cited as SHEPPARD \& RIX];

Califano, Joseph A., Jr. Remarks before the American Academy of Political and Social Science (April 8, 1978) [heremafter cited as Califano Remarks].

1. Sheppard \& Rix 1-2; see U.S. Bureau of The Census, Dep't of Commerce, CuRRENT POPUlation REPORTS, series P-25, Nos. 310, 311, 519, 643 and 704. The median age of the population in 1970 was 28 . It is expected to reach 30 by 1980 and 35 by 2000 . Americans Change, Bus. WEEK, Feb. 20, 1978, at 64.

2. ShePPARD \& RIX 1. The aging trend of the population is attributable to a number of important factors. First, life expectancy in the United States has imcreased from an average of $63 \frac{1}{2}$ years in 1940 to 69 for men and 77 for women. Califano Remarks 3. Three quarters of the 
the population raises serious policy questions of how best to cope with the cliange.

Numerous concerns liave been raised regarding the provision of adequate retirement imcome for the growing number of older people. ${ }^{3}$ The need to provide retirement imcome for an older population has

population attain the age of 65 . Id. Once there, they will, on the average, live to the age of 81 . Second, the fertility rate (number of children born to the average female) is decreasing. Americans Change, Bus. WeEk, Feb. 20, 1978, at 65. Froin 3.8 in the mid-1950s, the fertility rate declined to 1.76 in 1976. Id. While some experts contend that this rate will continue to fall, the Census Bureau predicts that the figure will eventually move up to 2.1 , the replacement level leading to a stable population. Id. 66. According to Professor Robert L. Clark, the social and economic trends affecting the fertility rate include failing marriage and rising divorce rates, deferred childbearing, the upswing in single-parenthood, two wage-earner and individual households, and higher educational levels. Other factors include the increased work experience and career opportunities for young women, the high cost of rearing and educating children, and the imcreasing use of birth control. Id. Finally, the post-war "baby boom" between 1946 and 1960 will become the "senior boon" in the next century, increasing the age of the population as a whole. Califano Remarks 3. See generally SHEPPARD \& Rix.

3. See 123 Cong. Rec. S16057 (daily ed. Sept. 30, 1977); 124 CoNG. Rec. S6584, S6586 (daily ed. May 1, 1978); 124 CoNG. REc. S15500, S15501 (daily ed. Sept. 19, 1978) (statements of Senator Javits); Hearings Before the Senate Governmental Affairs Comm. on Reorganization Plan No. 4 of 1978, 95th Cong., 2d Sess. 2 (1978) (statement of Senator Javits). See also 124 CoNG. REC. S6581 (daily ed. May 1, 1978) (statement of Senator Williams); Remarks of Senator Wilhams, International Foundation of Employee Benefit Plans (May 23, 1978); Remarks of Senator Williams, Employee Benefit Trusts Workshop, Trust Division of the American Bankers Association (Sept. 15, 1978); Remarks of Senator Williams, American Council of Life Insurance (Nov. 2, 1977).

In this vein, nunterous questions have been raised, imclutling the following: Will it be necessary or feasible to raise Social Security taxes snbstantially as the ratio of active workers to retired citizens changes from six to one today to three to one in 2030 ? Califano Remarks 4 . Will it be necessary to raise the age for normal Social Security benefits from 65 to 68 years in an effort to slow down the present trend toward early retirement which has the tendency of increasing the costs of the Social Security system as well as public and private pension plans? This latter proposal was advanced as part of the Minority House Ways and Means Committee program for financing the Social Security system. See 123 CoNG. REC. E5454 (daily ed. Sept. 9, 1977); Secretary of Coinmerce Kreps also suggested the possibility of raising the normal retirement age for Social Security benefits. See Statement on Worklife Extension by Juanita M. Kreps, Secretary of Comnerce, in Washington, D.C. (Aug. 5, 1977). With regard to early retirement, Secretary Califano has noted that

[In 1948] nearly one-half of all neen 65 years and over remained in the workforce. Today, among people 65 and over, only one man in five and one woman in twelve, are in the workforce. . . . [I]n 1963, only 23 percent of workers 45-54 indicated they intended to retire early; by 1976 , this had risen to 41 percent.

Califano Remarks 4.

$$
r
$$

During the period 1955 to 1977 , "the participation rate of 65-69 year olds las declined at a rate of nearly 40 percent. Among males, the ratio of years of work to years of retirement has declined froin 14:1 to about 5:1 during this century." SHEPPARD \& Rix 4. See generally Hearings on $S .1784$ Before the Subcomm. on Labor of the Senate Comm. on Human Resources, 95th Cong., Ist Sess. (1977); Hearings on H.R. 65 and H.R. IIIS Before the Subcomm. on Employment Opportunities of the House Comm. on Education and Labor, 95th Cong., 1st Sess. (1977); When Retirement Doesn't Happen, Bus. WeEk, June 19, 1978 at 72; Special Reports: Early Retirement, Employee Benefit Plan Review, Sept. 1978, at 16; see also ShEPPARD \& Rix 8-12, 104-15. 
stimulated discussion of the respective roles of Social Security and private retirement programs. ${ }^{4}$ In light of the apparent inability of private retirement plans to keep pace with inflation, ${ }^{5}$ the inadequate funding of soine retirement prograins ${ }^{6}$ and the uneven distribution of private pension benefits, ${ }^{7}$ soine observers have questioned whether it might inake better sense to curtail tax incentives that encourage private plans and apply the resulting revenue gains to inore generous and widespread Social Security coverage. ${ }^{8}$ Other observers have questioned the continuing financial solvency of Social Security, which is not advance-funded, and have advocated the expansion of private retirement plan coverage and benefits in light of the important role private plans play in supplementing Social Security benefits and in providing large pools of capital that can stimulate economic growth.'

There is no one solution to the proble1n of providing adequate retireinent incoine for older Americans. One approach, which involves

4. Compare 12 CoNG. REC. $\$ 15500-01$ (daily ed. Sept. 19, 1978) (statement of Senator Javits) and Hearings Before the Senate Governmental Affairs Comm. on Reorganization Plan No. 4 of 1978, 95th Cong., 2d Sess. 2 (1978) (statement of Senator Javits) with Califano Remarks. See generally N. TuRe, The Future of Private Pension Plans (1976).

5. See Califano Remarks 17-18; see generally R. SCHMIDT, MAJOR IsSUES FACING THE PRIvate Pension System 25-26 (Education and Public Welfare Division, Congressional Research Service, Library of Congress, Jan. 27, 1978); SHEPPARD \& RIX 132-33.

6. The size of unfunded pension liabilities has received considerable attention. See, e.g., Hearings on S. 2992 Before the Subcomm, on Private Pension Plans and Employee Fringe Benefits of the Senate Comm. on Finance, 95th Cong., 2d Sess. (1978); Remarks of I. Lanoff, ERISA Workshop Group, Cornell University (May 22, 1978); Pensions-A S100-Billion Misunderstanding, N.Y. Times, Jan. 4, 1978, at A-18, col. 1; Remarks of I. Lanoff, the Institutional Investor Conference (Jan. 13, 1978); Letter fron Senator Javits, N.Y. Tunes, Feb. 4, 1978, at 18, col. 1; A.F. Ehrbar, Those Pension Plans Are Even Weaker Than You Think, FORTUNE, Nov., 1977, at 104; Unfunded Pension Liabilities, Bus. WeEk, July 18, 1977, at 86; Rankin, Worrying About the Pension Gap, The New York Times National Economic Survey 64 (Jan. 8, 1978). See generally J. TreyNor, P. Regan \& W. Priest, Financial Reality of Pension Funding Under ERISA (1976).

7. Califano Remarks 18.

8. Revenue losses arise from a number of special tax incentives imcluding: an employer deduction for contributions to a qualified plan; a tax exemption for the income earned by a trust that forms part of a qualified plan; the forbearance from taxing employees on benefits under the plan until benefits are distributed; the special treatment of lump sum distributions from qualified plans through tax-free rollovers and 10-year forward income averaging; and certain estate and gift tax exclusions. See Califano Remarks 18. See generally M. Bernstein, the Future of PRIVATE PENSIONS (1964).

9. 124 CONG. REc. S15500 (daily ed. Sept. 19, 1978) (statement of Senator Javits).

Based on Securities and Exchange Commission and Federal Reserve Flow of Funds Accounts year-end 1976 figures, it is estimated that the book value of private noninsured pension assets for spring 1978 total $\$ 182$ billion and that private insured pension assets total $\$ 91$ billion. J. RIFKIN \& R. BARBER, THE NORTh Will RISE AGain 235 (1978). Currently, 20 to 25\% of the equity in American corporations and $40 \%$ of the bonds are held by pension funds, including private, state and federal plans. Id. 10. It is said that "Pension funds are now the largest source of investment capital for the American capitalist system." Id. 
expanding the role that private retirement plans ${ }^{10}$ play, is embodied in numerous proposals to amend the Employee Retirement Income Security Act of 1974 (ERISA) ${ }^{11}$ and the Internal Revenue Code (IRC) that were before the Nimety-fifth Congress and are presently before the Ninety-sixth Congress. This Article will focus on these proposals to expand the coverage and benefits of private retirement plans, briefly describing each proposal and discussing its relative merits.

\section{Proposals for Expansion of Private Retirement Plan COVERAge}

A government study indicates that in 1975 only $46.2 \%$ of all private industry wage and salary workers were covered by retirement plans. ${ }^{12}$ This percentage represents 30.3 million wage and salary employees. ${ }^{13}$ Although these figures compare favorably to those of earlier years, ${ }^{14}$ even more workers inust be covered by plans if minimal retirement benefits are to be provided to a broad cross-section of a progressively aging population..$^{15}$

During the Ninety-fifth Congress, ${ }^{16}$ three important ideas were advanced for increasing retirement plan coverage. Two were set forth in S. $3017,{ }^{17}$ which would permit financial institutions ${ }^{18}$ to establish special master plans ${ }^{19}$ and would grant tax credits to small employers who establish new plans. ${ }^{20}$ The third idea was contamed in S. 3140, which would permit employers to contribute up to the annual $\$ 7,500 \mathrm{Keogh}$ plan limitation to a separate individual retirement account (IRA) for

10. The term "private retirement plans" includes: ERISA-covered employee pension benefit plans as defined by Section 3(2) of the Employee Retirement Income Security Act of 1974 (ERISA), 29 U.S.C. § 1002(2) (1976); and non-ERISA Title I trusts such as Individual Retirement Accounts under section 408 of the Internal Revenue Code.

11. 29 U.S.C. $\S \S 1001-1381$ (1976).

12. U.S. Social Securtty administration, Dep't of Health, Education and Welfare, Social Security Bull. No. (SSA) 78-11700, at 21-22 (Nov. 1977).

13. Id. $19,21$.

14. For example, in 1950 only 9.8 million wage and salary employees were covered by retirement plans, comprising $22.5 \%$ of that class of workers. In 1960, 18.7 million wage and salary employees, that is approximately $37.2 \%$ of such workers, were covered by retirement plans. Id. 20 , 22.

15. See statements of Senators Javits and Williams, supra note 3.

16. Most of the proposals which were not approved by the Nimety-fifth Congress have been reintroduced in the Ninety-sixth Congress. Where appropriate, reference to the new bill(s) will be made.

17. The introductory statements accompanying S. 3017 appear at 124 CoNG. REC. S6584 (daily ed. May 1, 1978).

18. The term financial institution includes banks, insurance companies and mutual funds.

19. S. $3017 \S 401(a)$.

20. Id. $\S 304$. 
each employee. ${ }^{21}$ A variant of this concept was included in the Revenue Act of 1978, which was signed into law on November 6 of that year. ${ }^{22}$ All three proposals are principally intended to encourage small employers to establish retirement plans. ${ }^{23}$

\section{A. Special Master Plan (SMP).}

S. 3017's SMP proposal builds upon existing rules permitting the sponsorship of master and prototype plans. ${ }^{24}$ As envisioned by the bill, an SMP is a master or prototype mdividual account employee benefit

21. S. $3140 \S 3$.

22. Pub. L. No. 95-600, 92 Stat. 2763. See H.R. Rep. No. 1445, 95th Cong., 2d Sess. (1978), reprinted in [1978] U.S. CODE CONG. \& AD. NEWS 7046; 1978 SENATE REPORT; H.R. REP. No. 1800 , 95th Cong., 2d Sess. (1978) (Conference Report), reprinted in [1978] U.S. CODE CONG. \& AD. NEWS 7198.

23. It is thought that small employers have the most difficult time complying with ERISA, see Hearings on $S .3017$ at 490 (statement of James D. McKevitt). It is also thought that the greatest growth in new retirement plan coverage may be achieved in the small business sector, see Hearings on S. 3017 at 296 (statement of Daniel I. Halperin). The principal purpose of the proposals discussed in this section-the special master plan, simplified employee pension, and the new plan tax credit-is to encourage employers who do not sponsor plans to establish new plans.

Bills like S. 3017 and S. 209 also contain provisions that are intended not only to encourage the sponsorship of new plans by removing deterrents to plan establishment, but also to encourage the continued maintenance of existing plans. To encourage plan maintenance and plan fornation, S. 3017 contains the following sections: reduction of paperwork (sections 221-228); facilitation of compliance with ERISA's minimum standards provisions (sections 231-236, 239, 251) and facilitation of compliance with ERISA's fiduciary responsibility provisions (sections 261-265). Similar provisions are contained in S. 3017's successor bill, S. 209.

In hight of the Supreme Court's reversal of the Seventh Circuit's decision in International Bhd. of Teamsters v. Daniel, 99 S. Ct. 790 (1979), S. 209 would provide prospectively that state securities laws and the antifraud provisions of the federal securities laws do not apply to ERISAcovered plans within as well as not within the scope of the Supreme Court's holding. (The decision covered only noncontributory, compulsory pension plans.) The bill would not affect any securities law rights that participants in non-Daniel type plans may have had prior to the bill's enactunent. In addition, S. 209 would prospectively make it unlawful for any person knowingly to misrepresent the terms and conditions of an employee benefit plan, the financial condition of a plan or the statns under the plan of any employee, participant or beneficiary. An mjured party would be permitted to bring a civil action for damages due to reliance on sucl misrepresentation. No plan would be liable for such damages, and no person would be liable with respect to a plan document required under ERISA or the IRC to the extent such document satisfies the requirements of these statutes. S. 209, $\S \S 153,154$.

24. Certain existing rules relating to master and prototype plans are contained in the following: Rev. Rul. 71-479, 1971-2 C.B. 238; Rev. Rul. 71-461, 1971-2 C.B. 227; Rev. Rul. 71-25, 19711 C.B. 115; Rev. Rul. 70-28, 1970-1 C.B. 86; Rev. Proc. 75-52, 1975 C.B. 49; Rev. Proc. 72-8, $1972-$ 1 C.B. 716.

The principal difference between a SMP and existing master or prototype plans is that, under the SMP, more legal responsibilities are assumed by the sponsoring financial institution. Under the SMP, for example, the financial institution would be legally responsible as administrator for preparing and filing the annual report (Fonn 5500 series) required under section 103 of ERISA. The financial institution would also have the legal dnty of preparing the summary plan description required under section 102(a)(1) of ERISA. In addition, the financial institution would apply for a SMP certificate indicating the tax-qualified status of the SMP under I.R.C. $§ 401$. 
plan, ${ }^{25}$ all the assets of which are controlled by one or more investment managers. ${ }^{26}$ The investment manager sponsoring the SMP is the master sponsor, ${ }^{27}$ and the employer participating in the SMP is the employer sponsor. ${ }^{28}$ The duties of the employer sponsor under Title I of ERISA are limited to making timely contributions and to furnishing such timely, complete and accurate infornnation as may be required by the SMP. ${ }^{29}$ Under the plan qualification provisions of the IRC, these duties are deemed initially satisfied as of the date on which the SMP joinder is executed between the employer sponsor and the master sponsor. ${ }^{30}$ Should the employer sponsor fail to make timely payinents or to furnish required information, the bill would require him to assume certain duties previously perforned by the master sponsor. ${ }^{31}$

In addition to the duties associated with managing the plan's assets, the inaster sponsor also serves as the administrator and the named fiduciary of each employer sponsor's plan. ${ }^{32}$ The inaster sponsor, however, does not have fiduciary or cofiduciary responsibility under sections 404 and 405 of ERISA to ascertain whether the inforniation required to be furnished by the employer sponsor under the SMP is accurate or complete. ${ }^{33}$ Similarly, the master sponsor has no fiduciary or cofiduciary responsibility upon failure of the employer sponsor to make timely contributions or furnish required information. ${ }^{34}$ In order to facilitate the efficient operation of Special Master Plans, certain reportimg and disclosure requirements are simplified, ${ }^{35}$ and certain fiduci-

25. Section 3 of ERISA defines an employee benefit plan as an "employee welfare benefit plan [29 U.S.C. § 1002(1) (1976)] or an employee pension benefit plan [29 U.S.C. $\$ 1002(2)$ (1976)] or a plan which is both an employee welfare benefit plan and an employee pension benefit plan." 29 U.S.C. § 1002(3) (1976).

26. S. 3017 \& 401(a) (adding new $\S 601$ (a)(2) of ERISA).

27. S. 3017 \& 401(a) (adding new $\S 601(a)(3)$ of ERISA).

28. S. 3017 \& 401(a) (adding new \& 601(a)(4) of ERISA).

29. S. 3017 \& 401(a) (adding new \& 601(b)(1) of ERISA).

30. S. 3017 \$ 401(a) (adding new \& 601(b)(2) of ERISA).

31. S. 3017 \& 401(a) (adding new $\& 601$ (e) of ERISA). The einployer sponsor's failure to meet his obligations will result in his being deenned the plan administrator. The master sponsor will cease to be the administrator and the named fiduciary of the employer sponsor's plan.

32. S. 3017 \& 401(a) (adding new $\S 601$ (c)(1) of ERISA).

33. S. $3017 \S 401$ (a) (adding new $\S 601$ (c)(5)(A) of ERISA).

Section 404 of ERISA imposes on fiduciaries such duties as the "prudent inan" rule, the "solely in the interest of the participant" rule, the "exclusive purpose" rule, and the asset diversification requirement. Section 405 of ERISA imposes liability on fiduciaries for breach of duty by another under certain circumstances.

34. S. 3017 \$601(a) (adding new $\$ 601(c)(S)(B)$ of ERISA).

35. S. 3017 \&601(a) (adding new $\S 601$ (c)(2)(3) of ERISA). Under these provisions, the master sponsor may prepare plan descriptions and summary plan descriptions containing provisions common to the plans supplemented by a description of each variation from the common provisions, In addition, the master sponsor may also prepare an annual report refiecting the aggre- 


\section{ary requirements are clarified. ${ }^{36}$}

An SMP will be approved by the administering agency ${ }^{37}$ only upon determination that the plan of the employer sponsor, in both design and operation, ${ }^{38}$ satisfies ERISA criteria as well as section 401 of the IRC. ${ }^{39}$ Upon the plan's approval, an SMP certificate will be issued to the master sponsor. For five years from the date of an employer sponsor's adoption of the SMP a duly notorized copy of this SMP certificate will be prima facie evidence that the plan meets certain ERISA and IRC standards. ${ }^{40}$

Froin a tax viewpoint, the major difference between the SMP proposal and existing Internal Revenue Service (IRS) procedures for corporate master plans is that the SMP einployer sponsor would have no need to apply for an IRS determination on the qualification of his plan. ${ }^{41}$ This elimination of the need to apply for a determination letter constitutes a key reduction of responsibilities for employers. Requiring, as has been suggested, all employer sponsors to "pay" for this reduction of duties through the imposition of faster participation and vesting standards would be a blunderbuss approach that may deter

gate assets of the master plan if the report also identifies, among other things, each employer sponsor and indicates the percentage of total assets attributable to each employer sponsor.

36. S. $3017 \S 401$ (a) (adding new $\S 601$ (c)(4) of ERISA). Under this section the statutory prohibited transactions exemption, contained in section 408(b)(2) of ERISA (relating to making arrangements with a party in interest for office space, or legal, accounting or other services for reasonable coinpensation), "shall be apphed as if any imvestinent manager sponsoring a SMP and any investınent inanager providing services to such a plan were a party in interest respecting such plan for a reason other than by virtue of such investınent manager's being a fiduciary." Id. This section also provides that the term "bank or similar financial institution" in section 408(b)(6) of ERISA, containing the ancillary services prohibited transaction exemption, means "any investment manager who is a inaster sponsor." Id. The term "sound banking and financial practice" in section 406(b)(6) of ERISA means "sound fiduciary practice" in the case of an investment manager other than a bank. Id.

37. Title I of S. 3017 would estabhish a smgle, independent agency, the Employee Benefits Commission. This new agency would be the administering agency for the SMP.

38. Certain commentators have criticized this standard because they doubt that the administering agency can determine that the employer sponsor's plan is nondiscriminatory "im operation" before the plan has been adopted and implemented. Hearings on S. 3017, at 1236-37 (statement of Ralph N. George, Jr.).

39. S. $3017 \S 401$ (a) (adding new $\S 601$ (d)(2) of ERISA).

40. S. 3017 \$ 401(a) (adding new $\$ 601$ (d)(4) of ERISA).

41. Hearings on $S$. 3017 , at 313 (statement of Daniel I. Halperin). Representatives of the Labor Department testified that the Department favored efforts such as the special master plan to extend pension coverage. However, they deferred to the Treasury Department with respect to whether the proposal is consistent with sound tax policy. Id. 139 (statement of Robert J. Brown). The IRS considers such an arrangeinent to be unworkable unless the employer plan covers all employees and lias full and immediate vesting. Id. 313 (statement of Damiel I. Halperin). Treasury officials have noted, however, that "if a master plan with potentially discriminatory standards were permitted to be qualified without individual examination, appropriate sanctions for marketing and establishing discriminatory plans would have to be developed." Id. 
many employers from adopting SMPs. A more refined approach could be utilized by the administering agency in decidimg whether a particular SMP should be qualified. For example, an SMP could be required to have several vestimg schedules, with faster schedules applicable to smaller employers who meet certain criteria. Indeed, it may be appropriate to impose certain sanctions on the party responsible for marketing an SMP with, for example, an inappropriate vesting schedule for a particular employer sponsor. ${ }^{42}$

A number of other suggestions have been advanced for improving the SMP proposal. One is to reduce further the paperwork and administrative burdens, the costs of which are passed on by the master sponsor to the employer sponsor. ${ }^{43}$ Another is to eliminate the denomination of the master sponsor as "administrator," "named fiduciary" and "investment manager" and, instead, to set out the specific responsibilities that are to be shifted to the master sponsor. ${ }^{44}$ Other

42. As the Halperin testimony noted, "[q]uestions must be addressed concerning the type of sanction, the effective date of the sanction, and the party on whom the sanction is to be imposed." Id.

43. Id. 747, 1387 (statements of William T. Gibb and Theodore R. Groom).

44. A number of problems have been raised with respect to making the master sponsor "the adminstrator," "named fiduciary" and "imvestment manager" of the employer sponsor's plan. As one critic has said:

[T]here is nothing in the bill that insulates master sponsors from being sued as plan administrators because they have prepared or distributed inaccurate reports or disclosure materials. Although master sponsors may not ultimately be liable for such inaccuracies, they would still have to bear the costs of defending such litigation.

In addition, under ERISA the plan administrator is required to furnish a summary plan description to all participants. This function is normally performcd by employers by means of hand delivery at the workplace in order to avoid the burden of maintaining aceurate current records of employee home addresses. It would, therefore, be inappropriate and unnecessarily burdensome to require unaster sponsors to perform this function.

Also, applying the plan administrator title to insurance companies would preclude them from relymg on Prohibited Transaction Exemption 77-9 to sell insurance products or mutual fund shares to a special master plan. . . .

Applying the "named fiduciary" title to master sponsors would also create probleins. One of the principal functions of a "nanied fiduciary" under ERISA is to select and retain investment managers. However, naster sponsors will generally not be selectimg and retaining others to serve as investment managers for their special master plans. Rather, they will normally manage the assets of the plan themselves . . . .

Named fiduciaries are also responsible under ERISA for making decisions on claims appeals. These appeals, however, commonly involve disputes over [workforcerelated] facts . . . the aceuracy of which would be the responsibility of the employer .... [Consequently,] the master sponsor is not only the wrong person to decide these appeals, but may inappropriately become involved in frequent bcnefit claims litigation that will result in unnecessary hitigation expenses.

Id. $1387-89$ (statement of Theodore R. Groom).

Also, questions have been raised with respect to Keogh plans. Permitting a distribution to an owner-employee prior to age $591 / 2$ may involve a prohibited transaction. One commentator pointed out that a

recent IRS private ruling indicates that if the institution is offering a plan which provides that distributions are made only pursuant to directions from the employer or from some other "Named Fiduciary", the institution will not be hable for following such directions. Might not an institution be foregoing its insulation by becoming Nanjed Fiduciary? 
proposals include expanding the SMP concept to embrace defined benefit plans $\mathrm{s}^{45}$ and delaying action on the SMP-related provision in S. 3017 that provides that shares of pooled investment funds operated by a bank or an insurance company that are sold to an employee benefit plan are not securities. ${ }^{46}$ The latter provision was intended to facilitate the interstate marketing of SMPs by banks and insurance companies but has been attacked by the mutual fund industry as a removal of protections for prospective sponsors of Keogh plans and IRAs. ${ }^{47}$

In light of comments received on S. 3017, a number of changes in

Id. 1236 (statement of Ralph George, Jr.).

The term "investment manager," as defined under ERISA, applies to those who manage plan assets on a discretionary basis. One commentator stated:

In many insurance company master and prototype programs, however, funding is provided through the insurance company's general account. As a result, im many cases the insurance company would not be managing plan assets and would not, therefore, be an investment manager within the meaning of ERISA. . . [T] he intent of this requirement was probably to limit the group of eligible "master sponsors" to qualified financial institutions . . . [but the way it is proposed raises problems for insurance companies].

Id. 1389 (statement of Theodore R. Groom).

45. Id. 1389, 1418 (statements of Theodore R. Groom and The International Umion, Umited Automobile, Aerospace and Agricultural Implement Workers of America (UAW)).

Concern has also been expressed that the master sponsor has no obligation with respect to ensuring the payment of employer sponsor contributions. A solution to this problem might be the imposition of a statutory obligation upon the master sponsor to notify the administering agency of delinquencies. Id. 407 (supplemental comments by the Pension Rights Center).

46. Id. 804, 847 (statement of the Investment Company Institute). The position of the Investment Company Institute has been opposed by the American Bankers Association. Id. 865 (statement and additional statement of the American Bankers Association).

47. One observer has stated:

Under current law the assets of corporate plans may be collectively invested regardless of the size of the company without registration under Section 3(a)(2) of the Securities Act of 1933. . . . Congress did not exempt Keogh plan [non-corporate plan] collective trusts specifically from registration under the 1933 Act but rather gave the SEC authority to exempt them. The SEC . . . has not exercised this authority, at least on a class basis. . . Banks with very few exceptions, however, have not registered their collective trusts for Keoghs but have rehied upon the intrastate exemption of Section 3(a)(11) of the '33 Act.

Id. 866-67 (statement of the American Bankers Association). Most banks that have established collective trusts for Keogh plans accordingly market them only intrastate.

The SMP proposal is written so that all small employers, regardless of the business organization, would be able to adopt the plan. Banks and imsurance companies that want to market SMPs to partnerships and pool the funds, but want to avoid registering under the 1933 Act, would continue to market such plans on an intrastate basis. The removal of the applicability of the securities laws to such pooled funds would permit the interstate marketing of SMPs to small non-corporate employers.

Mutual funds representatives claim that S. 3017 would permit banks

to advertise interests in their pooled investment funds to employee benefit Keogh plans and IRAs, with no restraints whatever imposed by ERISA or the federal banking laws .... Banks will not be required to provide employee benefit Keogh plans and IRAs with prospectuses. . . [and] all employee benefit plans will lose the right to bring actions under the federal securities laws for fraud and misrepresentations in connection with their purchases of shares of pooled investment funds.

Id. 836-38 (statement of the Investment Company Institute). 
the SMP proposal are contained in S. $209,{ }^{48}$ the successor ineasure to $S$. 3017 in the Ninety-sixth Congress. S. 209 refers to the inaster sponsor as a fiduciary rather than the "named fiduciary" 49 and incorporates certain elements of ERISA's "investınent manager" definition into the definition of "master sponsor" rather than requiring the master sponsor to be an investment manager. ${ }^{50}$ S. 209 would also permit defined benefit as well as defined contribution SMPs ${ }^{51}$ and would permit the adopting employer ${ }^{52}$ to assume responsibility for furnishing certain required documents (such as the summary plan description) to participants, beneficiaries and employees. ${ }^{53}$ In addition, S. 209 would permit a master sponsor to seek a declaratory judgment if the Treasury Department fails or refuses to concur with the Labor Departinent in approving an SMP $^{54}$ and would permit the Treasury Department to disapprove retroactively an adopting employer's plan only if the failure to meet the IRC's requirements resulted from the employer's intentional failure or willful neglect. ${ }^{55}$ With respect to interests in certain collective imvestment media being considered securities, S. 209 narrows the scope of S. 3017 and requires the Secretary of Labor to promulgate regulations protecting participants and beneficiaries of plans that are funded by such pooled funds. ${ }^{56}$ On May 16, 1979, the Senate Labor and Human Resources Committee approved S. 209's SMP proposal, although it eliminated the collective investment media provision and permitted savings and loan institutions to becolne SMP master sponsors.

48. S. 209. The co-sponsors' introductory statements appear at 125 CONG. REC. S557-576 (daily ed. Jan. 24, 1979). See generally Hearings on S. 209 Before the Senate Labor and Human Resources Comm., 96th Cong., 1st Sess. (1979).

49. S. 209 \& 301(a) (adding new § 601(c)(1) of ERISA).

50. S. 209 § 301(a) (adding new $\S 601$ (a)(2) of ERISA).

51. S. 209 \&301(a) (adding new §601(a)(1) of ERISA).

52. S. 209 uses the term "adopting employer" in heu of S. 3017's "einployer sponsor." S. 209 $\S 301$ (a) (adding new $\$ 601(a)(3)$ of ERISA).

53. S. 209 \& 301(a) (adding new § 601(e)(2) of ERISA).

54. S. 209 \&301(a) (adding new $\$ 601(d)(2)(B)$ of ERISA).

55. S. 209 \&301(a) (adding new $\S 601$ (d)(7) of ERISA).

56. S. $209 \S 154$ (b) (adding new $\S 516$ of ERISA). The bill provides that an interest in a bank's single or collective trust or an insurer's separate account that is issued exclusively to enployee benefit plans is not a security for purposes of the registration requirements of the 1933 and 1934 federal securities acts (the federal securities anti-fraud provisions continue to apply, however) or within the meaning of any state securities laws. Such a trust or account holding exclusively plan assets shall also not be characterized as an investinent company under the Investinent Company Act of 1940 or state laws regulating investment companies. In addition, the Secretary of Labor is directed to prescribe regulations to protect participants and beneficiaries of plans wholly or partially funded by such pooled funds. Such regulations must include standards ensuring full and fair disclosure of all material facts and standards for accuracy in the advertising and publicizing of such pooled funds. S. $209 \S 154(\mathrm{a})(3)$ (adding new $\S 514(\mathrm{~d})(3)$ of ERISA). 


\section{B. Tax Credit for New Plans of Small Business Employers.}

Another provision of S. 3017 aimed at encouraging small employers to estabhish retirement plans would grant a five year declining tax credit to small business employers ${ }^{57}$ who establish new ${ }^{58}$ qualified employer retirement plans. ${ }^{59}$ The tax credit for the first taxable year of the new plan maintenance ${ }^{60}$ would be five percent of the amount allowable to such an employer as a deduction for his contributions to the plan. ${ }^{61}$ The credit would decline to three percent for the succeeding two taxable years and to one percent for the next two years, no longer being available in the sixth taxable year. ${ }^{62}$ According to Treasury Department officials, a narrower focusing of this credit could perhaps increase its effectiveness. ${ }^{63}$ However, further study of the sufficiency of information about the gap in pension coverage is necessary so that the credit can be fashioned to maximize new plan formation at an acceptable level of revenue loss. ${ }^{64}$

A different tax credit concept has been proposed to confront the phenolnenon that administrative costs per participant usually increase sharply as plan size decreases. ${ }^{65}$ The proposal would grant a contimuing credit for all plans. However, this credit would be calculated by multiplying the number of participants in a plan by an inversely proportional amount of money. That is, the anount of money contamed

57. Such an "employer" is defined as "an employer (within the meaning of [I.R.C.] section 404) whieh is a sinall business (as determined by the Adminstrator of the Small Business Administration under section 112 of the Small Business Act.)." S. 3017 \$304(a) (adding new I.R.C. $\S 44 \mathrm{C}(\mathrm{c})(2))$.

58. S. 3017 \& 304(a) (adding new I.R.C. §§ 446(b)(1), (2), (3)).

59. S. 3017 \& 304(a) (adding new I.R.C. \$ 446(c)(1)). A qualified employer retirement plan includes qualified corporate and Keogh plans. The credit is not allowed for contributions to Employee Stock Ownership Plans, see S. 3017 § 303(a) (adding new I.R.C. § 221(c)(3)), but is allowed with respect to commencement of contributions to ongoing qualified einployer retirement plans.

60. No credit would be allowable if an employer terminates a qualified employer retirenent plan at any time after January 1, 1978. This tax credit would have originally been effective for taxable years beginning after December 31, 1978. tion.

61. S. 3017 \& 304(a) (adding new I.R.C. \& 44C(b)). I.R.C. \& 404 permits the employer deduc-

62. S. 3017 \& 304(a) (adding new I.R.C. § 446(b)).

63. Hearings on $S$. 3017, at 312. (statement of Daniel I. Halperin). The credit could be targeted to "employees whose work force has a low average pay, those whose income is below specified levels, or those who have a relatively sinall amount of assets." Id.

64. Id. 311-12.

65. Id. 1359. (statement of Price Waterhouse \& Co.). A study completed for the Labor Department entitled Assessment of the Impact of ERISA on the Administrative Costs of Small Retirement Plans demonstrates that economies of scale constitute a major influence on plan adminstrative costs. See Estimates of Administrative Costs of Small Retirement Plans, 1974-1976, U.S. Department of Labor, Labor Managinent Services Administration (May 1, 1978) (mimeograph), for the Labor Department's comments on the Price Waterhouse study. 
in the credit would increase as the plan size decreased. ${ }^{66}$. This credit functions as a subsidy to small plans to cover the increased administrative costs attributable to ERISA. ${ }^{67}$

The proposed new plan tax credit in S. 3017 has been criticized because it would, in effect, penalize those employers who already have established pension plans and reward those who have not. ${ }^{68}$ The credit lias also been opposed because it would discriminate among employers participating in multiemployer plans solely on the basis of their size. ${ }^{69}$ The proposed credit could be improved, in the view of some, by makmg it applicable only to new defined benefit pension plans that better protect employees. ${ }^{70}$

In an attempt to target the credit to those small employers who, but for the tax incentive, could not afford to establish pension plans, the revised proposal before the Ninety-sixth Congress, as contained in S. 209, would inodify S. 3017's definition of "small business employer." Under the new bill, such an employer would be one who, during the taxable year immediately preceding the taxable year in which the credit is first claimed, had a monthly average of fewer than 100 employees. In addition, the "small business employer," if a corporation, must have earnings and profits, or if an unincorporated trade or business or a partnership, must liave net profits, during the period just described equal to no greater than $\$ 50,000 .^{71}$

\section{Simplified Employee Pension.}

The third important proposal advanced during the Ninety-fifth Congress to increase retirement plan coverage was contamed in $S$. 3140. The bill would expand the existing concept of employer-sponsored IRAs ${ }^{72}$ by authorizing deductible employer contributions to suclr an IRA. The employer contribution to each such IRA would be limited to the lesser of fifteen percent of gross income or $\$ 7,500$, the present Keogh plan limits. ${ }^{73}$

66. Hearings on S. 3017, at 1358-59 (statement of Price Waterhouse \& Co.).

67. Id. 1358.

68. Id. 358-366 (statement of Bert Seidman).

69. Id. 421 (statement of Robert A. Georgine).

70. Id. 701, 1417 (statements of American Society of Pension Actuaries and UAW).

71. S. 209 \& 204 (adding new I.R.C. § 44D(c)(2)). See generally Hearings on S. 209, supra note 48; Hearings on S. 75, S. 95, S. 209, and S. 557 Before the Subcomm. on Private Pension Plans and Employee Fringe Benefits of the Senate Comm. on Finance, 96th Cong., 1st. Sess. (1979).

72. Employer sponsored IRAs are provided for under I.R.C. § 408(c). Deductible contribu-. tions to these IRAs can be made only by employees, not employers. See Hearings on S. 3140 Before the Subcomm. on Private Pension Plans and Employee Benefits of the Senate Finance Comm., 95th Cong., 2d Sess. 2 (1978) (statement of Daniel I. Halperin).

73. S. $3140 \& 3$. 
The simplified plan, which is a defined contribution plan funded exclusively by employer-sponsored IRAs, ${ }^{74}$ would have to meet a combination of requirements under the IRC's IRA and qualified Keogh plan provisions. ${ }^{75}$ Consequently, participation would have to be nondiscriminatory, the maximum participation requirement would be three years of service, and employer contributions would be fully and immediately vested. ${ }^{76}$ If an employer's contribution for an employee were less than the annual IRA limitation of the lesser of $\$ 1,500$ or fifteen percent of annual compensation, the individual could contribute the difference. ${ }^{77}$ An individually designed, simplified plan would be subject to IRS approval and existing reporting and disclosure requirements. $^{78}$

S. 3140 was significantly modified by the Senate Finance Committee, ${ }^{79}$ and, as amended, was enacted into law as part of the Revenue Act of $1978 .{ }^{80}$ The final version, which was called a simplified employee pension, shifted from the employer-sponsored IRA to the more common employee-sponsored IRA or individual retirement annuity as the basic funding vehicle. ${ }^{81}$ The limitation on deductions for employer contributions to the IRA would be the present Keogh plan limits, and the employee could contribute the difference between the individual IRA limitation and the employer contribution. ${ }^{82}$ The employer would be entitled to a deduction for his contributions to each IRA under IRC $\S 404$, and the employee would be entitled to a deduction for the employer contribution to his or her IRA under IRC \& $219 . .^{83}$ The employee deduction would be allowed even though the employee was an active participant in a qualified plan, a governmental plan or a taxsheltered annuity. However, make-up contributions would not be permitted. $^{84}$

Under the version enacted, employer contributions must be made under a written formula followed by the employer, and the account or

74. Id. \& 2(4).

75. Id. $\$ \$ 2(4), 3(\mathrm{a})$.

76. Hearings on $S .3140$, supra note 72 (statement of Daniel I. Halperin).

77. S. 3140 \& 3. This provision embodies a limited IRA concept in which the employee can supplement employer contributions up to the IRA limit.

78. S. 3140 \& 3(a).

79. 1978 Senate Report 91-93, reprinted in [1978] U.S. CODE CoNG. \& AD. News 6854-56.

80. See note 22 supra.

81. H.R. ReP. No. 1800, supra note 22, at 21I-12; 1978 SENATE REPORT 9I-93, reprinted in [1978] U.S. CODE CONG. \& AD. NEws 6854-56.

82. H.R. Rep. No. 1800, supra note 22, at 211-12; 1978 SENATE REPORT 92, reprinted in [1978] U.S. CODE CONG. \& AD. NEws 6855.

83. Pub. L. No. 95-600, §§ 152(c) \& (f), 92 Stat. 2763 (1978).

84. 1978 Senate Report 93, reprinted in [1978] U.S. Code Cong. \& AD. News 6856. 
annuity must be maintained solely by the employee. The formula must provide nondiscriminatory contributions for a calendar year for each employee who has attained age twenty-five and has performed service for the employer during any part of three of the immediately preceding five calendar years. ${ }^{85}$ The employer's formula may provide, however, that employer contributions for each employee be reduced by the amount of the employer's share of Social Security tax. The Secretary of the Treasury is authorized to require such reports as may be required to carry out the purposes of these provisions. ${ }^{86}$

The final version of the S. 3140 proposal apparently constitutes an attempt to cut down on the reporting and tax qualification requirements that were apphicable under S. 3140. The final version is also an attempt to avoid the possible application of Title I of ERISA to such simplified employee pensions.

\section{Proposals for the Expansion of Retirement Plan BENEFITS}

As a coinplement to the expansion of private plan coverage, the Ninety-fifth and Ninety-sixth Congresses have looked into ways to expand private plan benefits in an attempt to meet the ever-increasing need for retirement imcome. This article now turns to a discussion of these legislative proposals to expand benefits.

\section{A. Proposals for Increasing Employee Contributions to Plans.}

One means of mcreasmg retirement benefits is to expand the role that employees play in contributimg directly toward their own retirement security. ${ }^{87}$ Presently, an employee who is not an active participant in a qualified pension plan, a tax-deferred annuity maintained by a tax-exempt institution or a governmental plan can make annual, deductible contributions to an IRA or an individual retirement annuity up to the lesser of $\$ 1,500$ or fifteen percent of compensation. ${ }^{88} \mathrm{De}-$ pendimg upon the terms of a qualified pension plan, an employee may also presently make mandatory or voluntary contributions to his or her plan, but generally no deduction or exclusion is available. ${ }^{89}$ Certain

85. Employer contributions are generally considered to be discriminatory unless they bear a uniform relationship to the first $\$ 100,000$ of each employee's total compensation.

86. H.R. ReP. No. 1800, supra note 22, at 211-12; 1978 SenATE REPORT 93, reprinted in [1978] U.S. Code Cong. \& AD. News 6856.

87. This assumes that employers will not reduce employer-paid benefits as employee contributions imcrease.

88. I.R.C. $\$ 408$.

89. 1978 Senate Report 88, reprinted in [1978] U.S. CoDe CoNG. \& AD. News 6851. 
tax incentives are provided, however, with respect to employee contributions to certain types of employee benefit plans including unfunded, nonqualified, deferred compensation plans, "cafeteria plans," and socalled "cash and deferred" profit sharing plans. ${ }^{90}$

Three tax imcentive concepts have been advanced in an attempt to encourage greater employee contributions to retirement plans. One would provide a deduction for employee contributions to qualified pension plans or IRAs. ${ }^{91}$ Another would permit a deduction for employee contributions to limited IRA arrangements. ${ }^{92}$ The third would permit homemakers to estabhish IRAs for theinselves. ${ }^{93}$ These ideas are aimed at increasing self-provided retirement benefits but may also result in increased retirement plan coverage. ${ }^{94}$

1. Deductions for Employee Contribution to Plans or Full Contribution IRAs. (a) Williams-Javits proposal. S. 3017 would permit a deduction for einployee contributions to a qualified employer retirennent $\mathrm{plan}^{95}$ not to exceed the lesser of ten percent of compensation included in gross income or $\$ 1,000$, reduced by twenty percent of the amount by which adjusted gross incoine exceeds $\$ 30,000 .{ }^{96}$ This deduction would be available for contributions to private as well as to government plans. ${ }^{97}$ Qualified plans would be required to accept employee contri-

90. Id. at 89 ; see Pub. L. No. 95-600, $\$ \S 132,134,135$, 92 Stat. 2763 (1978). During hearings, Treasury Department officials stated that the law on the tax treatment of employee contributions to tax-favored employee benefit plans "now goes in many directions, due to the variety of types of employee benefit plans in existence and the varying approaches to the treatment of employee contributions to them." Hearings on S. 3017, at 307 (statement of Daniel I. Halperin). Earher, the Treasury had suggested that Congress and the Treasury

[t]ogether begin to give serious consideration to the possibility of deductions and exclusions for employee contributions to all types of tax-favored deferred compensation arrangements and fringe benefit plans. We pointed out that it seems to us that a unified system could be developed under which anounts set aside at the employee's election are deductible or excludable if the arrangements are nondiscriminatory with respect to both coverage of employees and benefits (or contributions) actually provided and where exId. cessive deferral is not created.

91. See S. 3017; H.R. 12561, 95th Cong., 2d Sess., 124 Cong. Rec. H3622 (daily ed. May 4, 1978) (sponsored by Congressman Conable); S. 3288, 95th Cong., 2d Sess., 124 CoNG. REc. S10683 (daily ed. July 13, 1978) (sponsored by Senator Dole).

92. See S. 2004, 95th Cong., Ist Sess., 123 Cong. Rec. S13713 (daily ed. Aug. 4, 1977).

93. See H.R. 4649, 95th Cong., 1st Sess., 123 Cong. Rec. H2582 (daily ed. March 24, 1977) (sponsored by Congressman Trible); S. 1783, 95th Cong., 1st Sess., 123 CoNG. Rec. S11106 (daily ed. June 29, 1977) (sponsored by Senator Anderson).

94. For exaniple, the homemaker IRA, see text accompanying notes $148-53$ infra, is a proposal to increase self-provided retirement benefits, but it also is a concept for expanding retirement plan coverage becanse it makes IRAs available to a new class of individuals.

95. S. 3017 § 303(a) (adding new I.R.C. \$ 221(c)(3), defining a qualified employer retirement plan).

96. S. 3017 \& 303(a).

97. Id. 
butions and place them in separate accounts. ${ }^{98}$ Discriminatory use of the deduction would be limited by the twenty percent offset requirement that would deny the deduction to individuals having adjusted gross incomes exceeding $\$ 35,000 .{ }^{99}$ The deduction would be of greatest benefit to those employees who do not stay long enough with an employer to vest fully and to participants in low-benefit plans who will receive minimal retirement benefits. ${ }^{100}$

Business groups as well as organized labor have criticized the proposal's requirements that plans must accept employee contributions and keep them im separate accounts. They claim that the administrative burden of compliance will be great, particularly for defined benefit and multiemployer plans. ${ }^{101}$ There is some inerit to this contention. However, the elimination of such requirements would mean that einployees would be able to make deductible contributions only if permitted by those who administer the plans.

Concerns have also been expressed that employers may feel less responsibility to provide retirement income for their workers if deductible employee contributions are permitted. ${ }^{102}$ Similarly, emphasis upon employee contributions may lead employers to require contributions as a condition to participating in the plans. Mandatory contributions would tend to disadvantage low income workers, who frequently cannot make such contributions and therefore forfeit the chance for a minimal employer-provided pension. ${ }^{103}$ Some, though, beheve that allowing deductible employee contributions will facilitate benefit improvements. ${ }^{104}$

(b) Conable-Dole proposals. H.R. $12561^{105}$ and S. $3288^{106}$ would allow an employee who is an active participant in a qualified plan to make a deductible contribution either to that plan or to an IRA of the lesser of ten percent of compensation for the taxable year or $\$ 1,000 .^{107}$ The deduction would be available without regard to income level, al-

98. S. 3017 § 303(c) (adding new I.R.C. § 401(k)).

99. Id. In the Treasury Department's view, this $20 \%$ offset can still result in discriminatory utilization of the tax benefit accorded by S. 3017 . Because phase-out begins only at $\$ 30,000$, an individual well above the median income level can make a full $\$ 1,000$ contribution. Hearings on S. 3017 , at 309 (statement of Daniel I. Halperin).

100. 124 CoNG. REc. S6589 (daily ed., May 1, 1978) (statement of Senator Javits).

101. See, e.g., Hearings on S. 3017, at 421-22, 767, 1356 (statements of Robert A. Georgine, William T. Gibb and Price Waterhouse \& $\mathrm{Co}$.).

102. Id. 1419 (statement of UAW).

103. $I d$

104. Id. 1355 (statement of Price Waterhouse \& Co.).

105. H.R. 12561, supra note 91.

106. S. 3288, supra note 91 .

107. H.R. 12561, supra note $91, \S(a)(1)$. 
though discrimination concerns are dealt with by treating employee contributions to the plan' as those of the employer. ${ }^{108}$ The deduction would not be available to self-employed imdividuals or participants in government plans, ${ }^{109}$ and the einployer would not be required to accept employee contributions. ${ }^{110}$

The Senate Finance Committee adopted a variation of this concept in its version of the Revenue Act of 1978, though it was subsequently deleted in conference. ${ }^{111}$ The Committee variation would have allowed deductible employee contributions either to qualified retireinent plans or IRAs. However, the annual deduction would be the lesser of ten percent of the employee's compensation and $\$ 1,000$ for voluntary contributions or $\$ 100$ for mandatory contributions. ${ }^{112}$ The lower limit for mandatory contributions reflects the concern that a deduction for such contributions would encourage shifting the burden of providing plan benefits from employer to employee. ${ }^{113}$

Under the Finance Committee's version, employee contributions made either to the IRA or to the qualified retirement plan would generally be treated as contributions by the employer. ${ }^{114}$ Such treatment would apply for purposes of the IRC's antidiscrimination rules and limits on benefits and contributions. ${ }^{115}$ Contributions made to an IRA by a participating einployee would be deductible only if funds are transferred to the IRA from the employer. ${ }^{116}$ Transferring funds by or through the employer permits appropriate recordkeeping and verification of prohibited discrimination. ${ }^{117}$ Employers would not be required to accept einployee contributions.

During testimony on H.R. 12561, after the Fimance Committee

108. Id $\S(b)$.

109. Id. \& (a).

110. Id

111. See H.R. 13511, 95th Cong., 2d Sess. $\$ 151$ (1978) (as reported by Mr. Long, with an amendment); 1978 SENATE REPORT 88-91, reprinted in [1978] U.S. CODE CONG. \& AD. NEWS 6851-54; H.R. Rep. No. 1800, 95th Cong., 2d Sess. (1978).

112. See 1978 Senate Report 89, reprinted in [1978] U.S. Code Cong. \& Ad. News 6852.

113. Id.

114. Id. 90, reprinted in [1978] U.S. CODE CONG. \& AD. NEws 6853.

115. Id. "Employee contributions are not treated as employer contributions for purposes of determining the employer's deduction for its own contributions to the plan or for purposes of applying the vesting and benefit accrual rules under the Code." Id.

116. Id.

An employer would not be able to hold funds for more than a reasonable period of time before transferring them to the IRA. At the option of the employer, the employee could be limited to a choice of one or a few IRAs, or the employee might be allowed to choose whatever IRA he or she wishes. However, funds could not be transferred to an IRA Id. which is a fixed premium annuity or endowment contract.

117. Id. 90-91, reprinted in U.S. Code CoNG. \& AD. News 6853-54. 
had adopted its modified proposal, Treasury officials voiced reservations as to the feasibility of channelling employee contributions through the employer with respect to multiemployer plans. ${ }^{118}$ Moreover, the revenue impact of the bill, calculated at approximately $\$ 875$ million, raises serious concern because the largest portion of such impact, approximately $\$ 500$ million, derives from deductions for employee contributions that are currently nondeductible. ${ }^{119}$ In addition, the Labor Department was said to be concerned about the application of fiduciary rules to amounts withheld by the employer prior to the transfer to an IRA. ${ }^{120}$

Early in the Ninety-sixth Congress, Senators Dole and Nelson introduced S. 75, ${ }^{121}$ which would allow a deduction for employee contributions to certain retireinent plans ${ }^{122}$ or to IRAs equal to the lesser of ten percent of compensation includible in gross imcome or $\$ 1,000 .{ }^{123}$ Like the earlier Dole proposal, S. 75's deduction would not be available to the self-employed or to participants in government plans. ${ }^{124}$ However, unlike the earlier proposal, discrimination in favor of the highly compensated ${ }^{125}$ would be controlled through a test ${ }^{126}$ requiring that the actual deferral percentage for highly compensated employees meet standards similar to those required for certain cash or deferred arrangements under the Revenue Act of $1978 .{ }^{127}$ Failure to meet this test would result in highly compensated employees not being allowed to deduct their contributions. ${ }^{128}$ S. 75 makes no distimction between mandatory and voluntary employee contributions.

A similar provision was proposed by Senators Williams and Javits in S. 209. ${ }^{129}$ This proposal, however, differs from the Dole-Nelson measure in that it would not allow an employee deduction if, under the

118. Hearings on H.R. 12561 Before the Subcomm on Oversight of the House Comm on Ways and Means, 95th Cong., 2d Sess. 10 (1978) (statement of Daniel I. Halperin).

119. Id.

120. Id.

121. S. 75, 96th Cong., 1st Sess., 125 CoNG. REC. S263 (daily ed. Jan. 18, 1979).

122. Id. $\$$ a (adding new I.R.C. \& 221(a)).

123. S. 75 , supra note 121 , § a (adding new I.R.C. $\$ 221($ c)(1)).

124. Id.

125. A highly compensated participant is defined as any participant who is more highly compensated than two-thirds of all participants but only if such participant's compensation for a plan year equals or exceeds the salary of an employee of the United States who is compensated at a rate equal to the annual rate paid for step 1 of Grade GS-14.

S. 75, supra note 121, § a (adding new I.R.C. § 221(c)(7)).

126. S. 754, supra note $121, \S$ a (adding new I.R.C. $\S 221$ (c)(6)).

127. Pub. L. No. $95-600, \S 135,92$ Stat. 2763.

128. S. 75, supra note $121, \S$ a, (adding new I.R.C. $\S 221(b)(4)$ ).

129. S. 209 \$203. See generally Hearings on S. 209, supra note 48; Hearings on S. 75, supra note 71; StafF of JoINT COMMITTEE on TAXation, Description OF S. 75, S. 94, S. 209 aND S. 
terms of a plan not in existence on January 1, 1978, employee contributions are mandatory or employer contributions are not made unless contributions by employees are made. ${ }^{130}$ The Williams-Javits proposal is also different in that it defines inore broadly the highly compensated group. ${ }^{131}$ This proposal was approved on May 16, 1979 by the Senate Labor and Human Resources Committee.

A third related proposal advanced early in the Ninety-sixth Congress is Senator Bentsen's bill, S. 557, which would permit an active participant in a qualified private pension plan to take a deduction for his or her contribution to the plan or to an 1RA equal to the lesser of 15 percent of compensation or $\$ 1,500{ }^{132}$ This amount, the present IRA contribution limit, is larger than the deductible amount that S. 75 and S. 209 would permit. S. 557 also differs from the other two bills in that it contains no antidiscrimination test. ${ }^{133}$

2. Deductions for Employee Contributions to Limited IRA Arrangements. ${ }^{134}$ (a) Arrangement to assist participants in low benefit plan. A number of proposals were inade in the Ninety-ifth Congress to allow an employee participating in a qualified pension plan to make a deductible IRA contribution equal to the difference between the employer contribution on his or her behalf and the IRA deduction limits of the lesser of $\$ 1,500$ or fifteen percent of compensation. ${ }^{135}$ The pro-

557 Relating to Deductions for Individual Retirement Savings and Treatment of TaX-Qualified Employee Plans (Comm. Print 1979).

130. S. $209 \S 203$ (adding new I.R.C. $\$ 221(\mathrm{~b})(5)$ ).

131. S. $209 \S 203$ (adding new I.R.C. $\$ 221($ c)(7)). S. 209 requires that the highly compensated participant be compensated at a rate equal to the annual rate paid for step 1 of grade GS-12 rather than GS-14.

132. S. 557, 96th Cong., 1st Sess., 125 CoNG. REC. S2187 (daily ed. March 7, 1979). See generally Hearings on $S$. 75, supra note 71; DESCRIPTION OF S. 75, supra note 129.

133. S. 557, supra note 132.

134. The term "Limited IRA Arrangement" is intended to refer to proposals for making the amount of the employee's deductible IRA contribution dependent upon either the size of the employer contribution to the qualified plan or the full vesting of the participant's accrued benefit under the plan. The tern "Limited Employee Retirement Account" (LERA) has not been used to avoid possible confusion. During the 94th Congress, the House passed H.R. 10612 (the 1975 Tax Reform Bill), 94th Cong., 1st Sess., 121 CoNG. REC. H11754 (1975), see H. REP. No. 94-658, 94th Cong., Ist Sess. (1975), which, among other things, would have permitted a deductible contribution by an employee who was an active plan participant equal to the difference between the employer's annual contribution to the plan and the IRA limit. The deductible employee contribution could have been made either to an IRA or to a LERA that was an account in the employer's plan (the plan had to be established prior to ERISA's date of enactment-September 2, 1974) to which the employee contribution would be credited. Since 1976, the terin LERA has occasionally been used to refer to the IRA to which the difference between the employer plan contribution and the IRA contribution limitation could be contributed. Because of the ambiguity of the term LERA, it will not be used.

135. S. 2004, 95th Cong., 1st Sess., 123 Cong. Rec. $\$ 13713$ (daily ed. Aug. 4, 1977) (sponsored by Senator Inouye); S. 2462, 95th Cong., 2d Sess., 124 CoNG. REc. S876 (daily ed. Jan. 31, 1978) 
posals are intended primarily to perimit employees covered by low contribution/benefit plans to supplement their retirement benefits. ${ }^{136}$ They would also have the effect of discouraging einployees from foregoing participation in their employer's plan and establishing IRAs, thereby jeopardizing the plan's tax qualification.

While these proposals may be viable if the employer's plan is a defined contribution plan in which the employer's annual contribution on behalf of each employee can be readily calculated, the concept becomes impractical when the employer's plan is a defined benefit plan. ${ }^{137}$ In such a plan, individual accounts for each employee are not inaintained, and the calculation to determine the employer contribution on behalf of each employee is complex. In the Senate Fimance Coinmittee's view, such arrangements would "necessarily result in substantial coinplexity and administrative problems for employers, einployees and the Internal Revenue Service." 138 The arrangements would also not assist those employees who participate in plans with contributions exceeding IRA limits but who, because of frequent job changes, never vest their accrued benefits. It thus appears that these proposals do not recommend themselves very highly and should be discounted accordingly.

(b) Arrangement to assist mobile employees. H.R. $13576^{139}$ would perımt a participant in a qualified nongovernmental plan to make deductible contributions to an IRA in an amount not exceeding the IRA limits until the participant is fully vested under the employer's plan. ${ }^{140}$ Under this bill, the employer would be required to notify the einployee when $100 \%$ vesting occurs and of the amount of accrued benefits at the

(sponsored by Senator Dole); H.R. 5147, 95th Cong., 1st Sess., 123 Cong. REc. H2227 (daily ed. Mar. 16, 1977) (sponsored by Congressman Oberstar); H.R. 7587, 95th Cong., 1st Sess., 123 CoNG. REc. H5365 (daily ed. June 2, 1977) (sponsored by Congressman Wolff).

136. See, e.g., 123 Cong. REc. H1545 (daily ed. Mar. 16, 1977) (statement of Congressman Oberstar).

137. See Hearings on S. 3017, at 306 (statement of Daniel I. Halperin).

138. 1978 SENATE REPORT 90.

139. H.R. 13576 (sponsored by Congressman Cornan). This bill was previously introduced as H.R. 13347, 95th Cong., 2d Sess., 124 CoNG. REc. H6295 (daily ed. June 29, 1978). The concept contamed in H.R. 13576 and H.R. 13347 was reimtroduced by Congressman Corinan in the Ninety-sixth Congress as H.R. 628, 96th Cong., 1st Sess., 125 CoNG. REC. H173 (daily ed. Jan. 18, 1979). H.R. 628 also proposes a deduction for employee contributions to qualified plans. The coinpanion Senate bill is S. 1428, 96th Cong., 1st Sess., 125 CoNG. REc. S8665 (daily ed. June 27, 1979), which was introduced by Senator Cranston.

140. H.R. $13576 \S 2$ (adding new I.R.C. $\$ \S 219$ (a), (b) \& (c)). The contribution can be made to a section 408(a) IRA, a section 408(b) individual retirement annuity, or a section 409 retirement bond. 
time from both employer and employee contributions. ${ }^{141}$ If the employee ceases to be an active plan participant, he or she would be treated as fully vested in the accrued benefit under the plan. ${ }^{142}$ An einployee's IRA contribution would be treated as employer contributions to the plan for antidiscrimination purposes. ${ }^{143}$

When full vestimg occurs, there would be a distribution from the IRA equal to the lesser of the employee's vested projected benefit under the employer's plan or the fair market value of the employee's interest in the IRA. ${ }^{144}$ This distribution would be taxed at ordmary rates. After the distribution, the employee could continue to contribute to the plan. ${ }^{145}$ Consequently, in a inore generous plan, there would be no further employee contributions to the IRA because plan contributions would exceed the IRA limits.

This proposal is superior in at least two ways to the low benefit arrangeinent previously discussed. ${ }^{146}$ First, it permits highly mobile employees, who never vest under qualified plans with contributions superior to the IRA limits, to contribute toward their own retirement security, yet, it permits participants im low benefit plans to continue making deductible contributions even after they fully vest under the plan. Second, the proposal requires that the potentially complex calculation of the einployer contribution to the plan be performed when the employee fully vests rather than every year before the full vesting year. ${ }^{147}$ However, from the IRS's vantage point, the proposal may be less desirable because participants will be able to take larger deductions during the years in which they are not fully vested, although the IRS will be able to tax the difference between the deductions under the two methods when full vesting finally occurs. The proposal may also be more difficult to explain to participants and could result in administrative difficulties.

3. Homemaker IRAs. H.R. $4649^{148}$ and S. $1783^{149}$ would allow a spouse who has no compensation for a taxable year to establish his or her own IRA and inake the presently deductible IRA contributions.

141. H.R. $13576 \S 2$ (adding new I.R.C. $\S 219(f)(4)$ ). This section does not apply to multiemployer deferred benefit plans and church plans.

142. H.R. $13576 \S 3$ (adding new I.R.C. $\S 409 A(c)(5)$ ).

143. H.R. $13576 \S 4$.

144. Id. $\S 3$ (adding new I.R.C. $\$ \S 409 \mathrm{~A}(\mathrm{a})$ and (c)). This distribution rule would not apply to multiemployer defined benefit plans and church plans. Id. $\S 3$ (adding new I.R.C. $\S 409 A(b)$ ).

145. Id. $\S 2$ (adding new I.R.C. $\$ 219$ (b)).

146. See text accompanying notes $135-38$ supra.

147. The calculation, however, would apparently have to be done annually for fully vested participants in plans where the IRA limits exceed contributions under the plan.

148. See note 93 supra.

149. See note 93 supra. 
The uncompensated spouse would be able to make his or her own IRA contributions regardless of whether the other spouse participated in an IRA or another retirement program. ${ }^{150}$

In light of the present usage of IRAs by higher imcome individuals, ${ }^{151}$ there are grounds for anticipating that the loonemaker IRA could possibly provide another tax-shelter for upper income couples and families. ${ }^{152}$ But despite this concern, interest in the proposal continues as demonstrated by the introduction of S. 94 and H.R. 1542 in the Ninety-sixth Congress. ${ }^{153}$

\section{B. Tax Credit for Improved Plans.}

There has been a continuing interest in Congress in requiring as rapid vesting of accrued benefits as feasible. ${ }^{154}$ More rapid vesting increases the chances that an employee will have an adequate pension upon retirement and lessens the need for developing complex schemes for increasing portability or reciprocity between plans. Of course, more rapid vesting will generally imcrease the cost of providing a pension benefit. ${ }^{155}$ It was in hight of this concern about more rapid vesting that the notion of an "improved plan" was put forward in S. 3017.

A plan would be certified as an improved plan if, for the plan year for which certification is requested, there has been a "substantial improvement" in benefits compared to the preceding plan year and if employee rights exceed Title I's minimum standards. ${ }^{156}$ The plan must permit "significantly earlier participation" than ERISA presently requires and "significantly more rapid" vesting than ERISA's "lcast rapid rate." 157 As an alternative to improved participation and vcsting,

150. 123 ConG. REC. H2582 (daily ed. Mar. 24, 1977) (statement of Congressman Trible). See generally Hearings on Individual Retirement Accounts and IRS Plan Termination Survey Before the Subcomm. on Oversight of the House Comm. on Ways and Means, 95th Cong., 2d Sess. (1978).

151. See Hearings on Individual Retirement Accounts, supra note 150, at 49, 54, 58 (statement of Daniel I. Halperin).

152. But see id. at $70-75$.

153. S. 94, 96th Cong., lst Sess., 125 CoNG. REC. S288 (daily ed. Jan. 18, 1979); H.R. 1542, 96th Cong., 1st Sess., 125 Cong. REC. H317 (daily ed. Jan. 25, 1979). See generally Hearings on $S$. 75, supra note 71; DESCRIPTION OF S. 75, supra note 129.

154. See 123 Cong. REc. S13528, S13532 (daily ed., Aug. 4, 1977) (statement of Senator Javits).

155. But see text accompanying note 162 infra. S. 3017 attempts to subsidize the potential cost increase of faster vesting by providing a five percent tax credit to employers who establish improved qualified employer retirement plans rather than directly requiring, for example, $100 \%$ vesting after five years of service. S. 3017 \$ 305 (adding new I.R.C. § 44D).

156. S. 3017 § 124(a). Under S. 3017, certification wonld be by the new Employee Benefits Commission.

157. Id. $\S 124(b)(1)(2)$. See section 202 of ERISA for minimum participation requirements and section 203 of ERISA for minimum vesting standards. 
a plan may provide "some other significant improvement" that is "at least equivalent" to the participation and vesting improvements. ${ }^{158}$

The draftsmen of the improved plan credit realized that there were technical problems ${ }^{159}$ with the proposal and that it gave too much discretion to the administering agency. ${ }^{160}$ They were also aware that there was an equitable problem with providing a tax credit prospectively to employers who may be less generous with their employees and denying a credit to employers who may have already provided five year, $100 \%$ vesting. ${ }^{161}$

One telling criticism of the proposal was raised with respect to the granting of the tax credit. Since cost does not necessarily increase because of improved participation and vesting, should the improved plan credit be permitted if vesting is improved but cost is not increased? ${ }^{162}$ For example, a plan with low employee turnover could change from ten year full vesting to five year full vestimg with hittle increased cost. ${ }^{163}$ Or, a profit-sharing plan with forfeiture reallocations could shift from ten year to eight year, $100 \%$ vesting with no cost imcrease. ${ }^{164}$ It may not be appropriate to grant a credit where, as in these two examples, employee rights are increased, but there are no increased employer contributions to subsidize. If the credit is to be granted only where there are cost increases, the administering agency will have to face complex actuarial probleins. ${ }^{165}$ No similar provision has been introduced in the Ninety-sixth Congress, and it seeins clear that further refineinent of this proposal is necessary.

\section{Joint and Survivor Annuity Protection.}

ERISA presently specifies that if a plan provides an annuity forn of benefit, the annuity must be in the form of a qualified joint and survivor annuity. ${ }^{166}$ The participant is entitled to "opt out" and select a single life annuity if that better suits his or her needs. ${ }^{167}$ During the period from the later of the plan's earhest retirement age or ten years before the normal retirement age, participants must have the option of

158. S. 3017 § 124(b)(3).

159. For example, what is the least rapid vesting rate under ERISA?

160. The proposal provided no guidance on what would constitute "significantly earlier participation" or "significant improvement." See S. 3017 \& 124(b).

161. See Hearings on S. 3017, at 421, 1417-18 (statements of Robert A. Georgine and the UAW).

162. See id. 312, 1359-60 (statements of Daniel I. Halperin and Price Waterhouse \& Co.).

163. Id. 312 (statement of Damiel I. Halperin).

164. Id. 1359 (statement of Price Waterhouse \& Co.).

165. Id. 312 (statement of Daniel I. Halperin).

166. ERISA \& 205(a).

167. Id. $\S 205(\mathrm{e})$. 
electing joint and survivor annuity coverage. ${ }^{168}$ If the participant so elects, the additional cost of the survivor protection can be charged to the participant through an actuarial reduction of the normal form of annuity. ${ }^{169}$ ERISA provides that, in the absence of joint and survivor annuity protection, vested, employer-derived benefits can be forfeited because of the participant's death, whether before or after retirement. ${ }^{170}$

In the view of many, one shortcoming in ERISA's protection against benefit forfeitures through death is the mapplicability of the joint and survivor annuity protection to the participant during most of his or her working life. Under the current rules, if an employee who is fully vested after thirty-five years of service dies shortly before an early retirement age of sixty-two, the plan is not required to pay a survivor's benefit to the spouse. ${ }^{171}$ S. 3017 attempts to overcome this lack of protection by requiring that in the case of a participant who dies and who is at least fifty percent vested nnder a plan that provides an annuity form of benefit, a survivor's benefit based upon the vested benefit inust be paid to the surviving spouse when the participant could have reached his or her earliest retirement age or sooner. ${ }^{172}$ In a similar case, under a plan that does not provide for an annuity benefit, a lump sum distribution to the surviving spouse of the participant's account balance would be required not later than sixty days after the end of the plan year in which the participant dies. ${ }^{173}$ The proposal essentially establishes an earlier date for the applicability of the automatic joint and survivor protection.

Commentators have observed that, particularly with respect to defined benefit plans, ${ }^{174}$ the proposed change would mandate in effect a preretirement death benefit as an ancillary benefit of a pension plan. ${ }^{175}$ Soine pension plans presently provide such death benefits, but in many cases einployers provide death benefits through separate life insurance plans that can be tailored to provide more effective coverage for young

168. Id. \& $205(\mathrm{c})(1)$.

169. Id. \& $205(\mathrm{~h})$.

170. Id. \& 203(a)(3)(A).

171. Hearings on $S .3017$, at 406 (supplemental comments by the Pension Rights Center).

172. S. 3017 \& 238. See H.R. 3340, 96th Cong. 1st Sess., 125 Cong. Rec. H1860 (daily ed. Mar. 29, 1979).

173. S. 3017 \& 238.

174. The bill essentially does not change current practice respecting defined contribution plans. Generally, the deceased participant's account balance is paid to a beneficiary. Hearings on S. 3017 , at 1350 (statement by Price Waterhouse \& Co.). Co.).

175. Id. 580, 1350-51 (statements of American Academy of Actuaries, Price Waterhouse \& 
employees. ${ }^{176}$ Tying death benefits to vested benefits could result in the making of minimal payments to survivors and would administratively burden the pension plan. ${ }^{177}$

However, enployers could react to the S. 3017 proposal by noving their group life coverage into their pension plans, resulting in loss by employees of the $\$ 50,000$ tax exclusion applicable to life insurance benefits under section 79 of the IRC. ${ }^{178}$ Employers could also conceivably impose mandatory employee contributions to pension plans to cover the additional cost of the expanded jomt and survivor annuity protection. ${ }^{179}$ Cost estimates by interested groups have ranged from a ten to fifteen percent increase $\mathrm{m}$ cost, but there are grounds for believing that these estimates may be too high. ${ }^{180}$ Whatever the cost mcrease would be, it would impact most heavily on those einployers who have provided faster than minimum vesting, ${ }^{181}$ including small employers who lave been forced by the IRS to adopt so-called 4-40 vesting. ${ }^{182}$

The S. 3017 joint and survivor annuity provision has been modified during the Nimety-sixth Congress in S. 209 to take account of soine of the criticisms leveled at the original proposal. S. 209 would make the expanded survivor protection applicable im the case of a participant who is credited with ten years of service for vesting purposes rather than one who is at least fifty percent vested. ${ }^{183} \mathrm{~A}$ plan that provides an annuity as the normal forn of benefit would be required to pay a deferred annuity to the surviving spouse of such a participant who dies, and could not nake a distribution earlier than the annuity starting date except if the payment, whether in the form of a luinp sum or imstall-

176. Id. 581, 784-85, 1351 (statements of American Academy of Actuaries, American Council on Life Insurance and Health Insurance Association of America, Price Waterhouse \& Co.).

177. Id. 784-85, 1351-52, 1422-23 (statements of American Council on Life Insurance and Health Association of America, Price Waterhouse \& Co., the UAW).

178. Id. 785 (statement of American Council on Life Insurance and Health Insurance Association of America).

179. Id. 1352 (statement of Price Waterhouse \& Co.).

180. Id. 420, 1001 (statements of Robert A. Georgine, Association of Private Pension and Welfare Plans). Estimates made for the Senate Labor Subcommittee place the increase at between two and five percent of cost.

181. Id. 785, 1352 (statements of American Council on Life Insurance and Health Insurance Association of America, Price Waterhouse \& Co.).

182. 4-40 vesting refers to the faster vesting schedule that the IRS may require certain employers to adopt in order to avoid actual or potential discrimination in favor of employees who are officers, shareholders, or highly compensated. This faster vesting schedule could require $40 \%$ vesting after four years of employment, an additional five percent for each of the next two years, and an additional $10 \%$ for each of the following five years. See Rev. Proc. 75-49, 1975-2 C.B. 584; Rev. Proc. 76-11, 1976-1 C.B. 550.

183. S. $209 \S 127(a)(2)$ (adding new $§ \S 205(b)(1)$ and (c) of ERISA). See generally Hearings on S. 209, supra note 48. 
ments, did not exceed $\$ 2,000 .{ }^{184}$ A plan that does not provide an annuity as the normal form of benefit would be required with respect to such a deceased participant to distribute the benefit to the surviving spouse in a lump sum or in installments not later than sixty days after the end of the plan year in which the participant dies or to distribute the benefit in some other manner agreed upon by the spouse and the plan. ${ }^{185}$ In addition, a plan would be permitted to take account in any equitable fashion any increased cost froin the expanded survivor protection. ${ }^{186}$ Because such increased cost could be borne by the participant, S. 209 would permit the participant to elect "out" froin coverage. ${ }^{187}$ In order to discourage defined contribution plans from dropping optional annuity forms of benefit because of IRS interpretations of the joint and survivor rules, S. 209 clarifies that a plan may provide that the normal form of benefit is a form other than an annuity. ${ }^{188}$ The S. 209 joint and survivor annuity proposal was approved by the Senate Labor and Human Resources Committee on May 16, 1979.

\section{Conclusions}

As the American population grows older, the demand for retirement income will increase. When the "baby booin" becomes the "senior boom" in the next century, it is conceivable that the demand for retirement benefits will become greater than the society's ability to provide such benefits. It is essential that comprehensive thinking and planning be done now so that a "retirement crisis" does not confront the nation early in the twenty-first century.

The proposals previously discussed are attempts to expand the role private retirenient plans play in providing retirement inconie. Through harnessing the coinpetitive energies of financial institutions interested m marketing new "products," the special master plan concept could become a key vehicle for expanding plan coverage. The adoption of SMPs as well as other plans could be enhanced by permitting the five percent declining tax credit for small employers, who generally are least able to sponsor plans but whose sponsorship of plans is essential if coverage is to be expanded. The simplified employee pension, which is now law, should contribute to increased plan coverage, but only tine will tell whether this retirement savings vehicle will be popular with employers and financial institutions.

184. S. 209 \& 127 (adding new $\S 205(b)$ of ERISA).

185. Id. $\& 127$ (adding new $\$ 205$ (c) of ERISA).

186. Id. \& $127(\mathrm{a})(7)$.

187. Id. $\$ 127(\mathrm{a})(5)$.

188. Id. $\S 127(\mathrm{a})(1)$ (adding new $\S 205(\mathrm{a})$ of ERISA). 
With the increasing need for retirement income and limitations on the amount einployers can afford to contribute to plans, employees should be encouraged to contribute toward their own retirement benefits. A proposal to permit deductible employee contributions to retireinent plans or full contribution IRAs was passed by the Senate in 1978 and may yet be enacted into law. The likelihood of enacting proposals permitting deductible employee contributions to limited IRA arrangeinents, however, seems to be waning somewhat due to the complexities associated with these concepts. The homemaker IRA, in contrast, is relatively simple. Yet, Congress must deal with concerns about revenue loss and disproportionate use by high-income taxpayers. Further refineinent is necessary with respect to the improved plan tax credit proposal, and more political support is needed for expanded jomt and survivor aunuity protection.

In addition to the foregoing proposals, more ideas inust be generated to improve retirement plan coverage and benefits and to deal with the entire retirement income question. Attention should be focused on the appropriate limits on integration between Social Security and private pension plans, and on the need and ability to pay for cost of hiving adjustınents to pension benefits. Assuming a modest five percent rate of inflation, fixed private retirement benefits would be decreased by fifty-four percent over fifteen years of retirement-the average life expectancy of retirees. ${ }^{189}$ Attention should also be focused on the relative roles of Social Security and private retirement plans in contributing to capital formation. Studies indicate that Social Security has had a substantial negative impact on savings, while private plans appear to contribute to increased aggregate saving and capital accumulation. ${ }^{190}$ In addition, an interesting area of inquiry is whether rapidly growing private retireinent plan assets should be used for "socially useful" purposes. Should plan assets, for example, be used to provide mortgages or housing for plan participants or others; or should such assets be used to save the declining Northeast section of the country or to encourage the growth of union jobs?

It is to be hoped that the President's Commission on Pension Policy ${ }^{191}$ and the National Commission on Social Security ${ }^{192}$ will deal with these and other important retirement income issues in a thorough

189. R. SCHMid, supra note 5, at 25.

190. Munnell, Private Pensions and Savings: New Evidence, 84 J. Polmical Econ. 1031 (1976).

191. The President's Commission on Pension Pohicy was established by Executive Order 12071 on July 12, 1978, and held its first meeting on March 23, 1979. Hearings on S. 532 Before the Subcomm. on Civil Service and General Services of the Senate Governmental Affairs Comm, 96th Cong., 1st Sess. (1979) (statement of C. Peter McColough). 
manner. Retirement imcome policy is a matter of high national priority that will only become more important as the "graying of America" continues. Througli proposals such as those discussed above, and other legislative, Presidential and private imitiatives, action can be taken in time to avoid a retirement income crisis.

192. The National Commission on Social Security was established by the Social Security Amendments of 1977, 42 U.S.C. $\$ \S 907 a, 401,1395,1395 d d$ (1977). 